Original Research Paper

\title{
Ancient Roman Civilization and Modern, Industrial Society A Contribution to the Sociological Theory of Long-Term Social Change
}

\author{
${ }^{1}$ Georg W. Oesterdiekhoff and ${ }^{2}$ Stefan Breuer \\ ${ }^{1}$ Institute for Sociology, Karlsruhe Institute for Technology, Karlsruhe, Germany \\ ${ }^{2}$ Institute for Sociology, University of Hamburg, Hamburg, Germany
}

\author{
Article history \\ Received: 22-01-2021 \\ Revised: 15-03-2021 \\ Accepted: 01-04-2021 \\ Corresponding Author: \\ Georg W. Oesterdiekhoff \\ Institute for Sociology, \\ Karlsruhe Institute for \\ Technology, Karlsruhe, \\ Germany \\ E-mail:Oesterdiekhoff@t-online.de
}

\begin{abstract}
Ancient Roman civilization had many technological, economical and institutional prerequisites to develop the modern, industrial society. However, it did not do so but collapsed instead. For centuries researchers try to find the explanations to the rise of modern, industrial society, to the collapse of the ancient civilization and to the differences between ancient and modern societies. Piagetian psychology can help to find answers to these questions. It is argued that the ancient Romans (ancient humans) were characterized by the preoperational psychological stage and failed to attain the formal operational psychological stage that emerged during the 17th century in Europe, at first in small circles and during the following centuries in the whole people living in modern, industrial societies. Thus, there is a huge psychological gap between ancient and modern peoples. The preoperational stage explains the religion, the magic, the morals and the social life of the ancient Romans, while the formal operational stage explains the decline of these ancient patterns and the rise of new social, political and moral structures during the past centuries, at first in the West and now on a worldwide scale.
\end{abstract}

Keywords: Ancient Roman Civilization, Modern, Industrial Society, Psychological Stages, Piagetian Psychology

\section{Introduction}

Piaget himself tried to apply his study of children to the study of history. He sometimes wrote that the best way to study the mind of the ancients be the study of present-day children because dead people cannot answer any more to research questions or be scrutinized in psychological laboratory. His books and works are full of descriptions that reveal similarities between the mind and worldview of the child with that of ancient humans. Piaget especially chose nature peoples and ancient philosophy as objects to expose these commonalities. When collecting all descriptions Piaget made with this regard it would be astonishing to see that they cover the whole range of psychological life, including the understanding of physics, morals, religion, law and politics (Oesterdiekhoff, 2016a). Despite that Piaget dedicated a central monograph to the comparison study only in one field, namely the study of the rise of physical sciences (Piaget and Garcia, 1989).

The Piaget following scrutiny of the connection between history, culture and society on the one hand and child psychology on the other hand went on two streets. The one was the empirical cross-cultural psychology that researched psychological stage developments right across nations, ethnicities, cultures, social classes andcontinents (Dasen and Berry, 1974; Dasen, 1977; Cole and Scribner, 1974; Mogdil and Mogdil,1976; Peluffo, 1967; Havighurst and Neugarten, 1955; Luria, 1982; Luria and Wygotski, 1992). As it found different peoples staying on different psychological stages it was clear that Piaget's own observations regarding the commonalities mentioned couldn't be totally wrong. However, most test psychologists weren't even able to see the contact between the empirical results concerning differences 
between premodern and modern humans on the one hand and Piaget's own descriptions of the commonalities mentioned on the other hand (Oesterdiekhoff, 2017c; Dux, 2011; Dux and Rüsen, 2014; Ibarra, 1994). Even Piaget himself (1974) did not even see the link between the empirical cross-cultural psychology and his own persuasion that child psychology be the key to reconstruct the historical development of psyche and mind! More, these field researchers had not even the slightest idea that their research could form the key to reconstruct the history of mind and consciousness. What was even more totally out of their view that they had the key in their hands to reconstruct the history of culture, society and economy (Oesterdiekhoff, 2017c). Piagetian cross-cultural psychology needed roughly 50 years of existence to find the first theoretically demanding comprehensions (Hallpike, 1979; Oesterdiekhoff, 2000; 2016c-d; 2018a; Dux, 2011; Dux and Rüsen, 2014).

The other way was to do just this thing, namely to apply Piagetian stages to the reconstruction of history. Dux (2011; Dux and Rüsen, 2014; Radding, 1985; Habermas, 1989; Breuer, 2014) applied Piagetian theory to the study of medieval and ancient European society, (Ibarra, 2007) did the same with the study of Pre-Columbian America, (Ziégler, 1968) with the study of developing nations, (LePan, 1989) with the study of the history of English literature, (Gablik, 1976) with the study of the history of arts and (Hallpike, 2004; Oesterdiekhoff, 2009; 2011; 2013a; 2012a) with the study of the history of morals.

Especially the structural-genetic theory programme provided by Oesterdiekhoff during the past 30 years reconstructed the whole history of population, society, economy, culture, language, mind, manners, politics, law, religion, philosophy, sciences and arts in terms of psychological stages. It has been described that psychological stages are the key to disclose the foundations of the historical developments of the branches mentioned. The lower stages constitute the core structures of the branches during their premodern times, while these branches all changed and advanced during modernization processes having taken place in the past few generations or centuries due to psychological stage advancements.

Here Piagetian psychology is applied to the comparison between ancient Roman civilization and modern, industrial society. Roman civilization with its technologies, political order, administration, traffic infrastructure, merchandise and division of labor had so many prerequisites to develop the modern, industrial society respectively to enter the way Europe went 250 years ago. However, it did not do so but collapsed totally (at least in its Western half). How much distant in terms of culture and development was the ancient empire from 18th century Europe? Piagetian psychology can contribute much to answer to this question. It is possible and necessary to apply the notions won by the empirical Piagetian cross-cultural psychology in the 20th century developing world to the psychological study of the ancient Romans (ancient humans). It is argued that ancient Romans were characterized by lower psychological stages typical for premodern peoples around the world. Their religion (nature cults, ancestor worship, etc.), their morals (slavery, arena games, etc.), their weakness in sciences, their politics (autocracy, etc.) and many other features originate in lower psychological stages and differ widely from that level of culture and civilization that characterized 18th century Europe. Thus, the argumentation shows that the psychological analysis of people contributes more to the explanation of these decisive historical issues than merely institutional or economic approaches do.

\section{The Relevance of the Comparative Study in Classic and Current Social Sciences}

The comparison of different societies with each other belongs to the normal business or procedure of social sciences since their beginning. Already (Aristotle, 1995) in his Politeia compares different governmental systems and societies with each other. 2.000 years later, Charles de Montesquieu does the same in his essay L'ésprit des lois. Even more than sociology, ethnology respectively cultural anthropology has contributed to the comparative method. Already Lafiteau in his oeuvre Les moeurs des sauvages ameriquaines comparées aux premiers temps of 1724-sometimes being held as the starter work of ethnology-compares the habits and customs of the Indians of North America to those of the ancient Mediterranean peoples. Basing on his great knowledge and amazing overlook, Lafiteau found remarkable similarities between the peoples of these two world regions and eras. Ethnology of the 19th and early 20th century collected the knowledge about the cultures and peoples right across the five continents and across the millennia in huge encyclopedias or in volumes resembling encyclopedias. Ethnology found astonishing resemblances between different premodern cultures. Despite many differences within their range they share many traits and peculiarities concerning customs, worldview, religion, morals, manners and mind. They all share commonalities that 
create a great gulf between the pre-modern and the modern world. Ethnology almost always emphasized that there are huge differences between pre-modern and modern, industrial societies-differences that overwhelm and overrun all those differences that might appear within the range of pre-modern societies itself. Ethnology and sociology found that modern societies manifest new patterns of mind, morals, customs and worldview that didn't exist in all history beforehand. With modern societies some new phenomena evolved that diverged from all what pre-modern cultures had manifested right across continents and time periods. These ethnological encyclopedias are worth reading by today, written by scholars such as Theodor (Waitz, 2017; Wundt, 2015; Bastian, 1884; Lubbock, 1913; Tylor, 1871; Frazer, 1927; 1994).

This method of comparing societies was also used by the first sociologists such as Auguste (Comte, 1988; Spencer, 2017) but too by later generations to which belong (Durkheim, 1912; Weber, 2019; Elias, 1982). This so-called classical sociology dedicated their works to the contrasting description of premodern and modern societies. It stood in the centre of their intellectual endeavors. These sociologists confirmed the judgment of the ethnologists according to that pre-modern and modern societies diverge a lot.

The more pre-modern societies disappeared from the planet's surface during the past 150 years the more their study and the relevance of their comparison to modern societies retreated without vanishing totally though. Contemporary social sciences rather prefer comparisons between present-day societies that is between societies that all fall in the range of modernity more or less. Differences between the socio-economic development of Russia and China after 1990, or between India and China during the past 50 years, or between East Asia and Latin America after 1945, or between single nations within Black Africa or within Latin America are in the focus of recent comparative studies. Frequently these studies aim to isolate and to earmark those factors that have been causing the divergent socio-economic developmental courses. The frequent question is why China succeeded so tremendously after 1978 while India developed in comparison slowly. By 1990 Russia was economically and culturally much stronger than China but during the past 30 years China has outperformed Russia amazingly. Which factors account for these divergences? -the try to answer to this question frequently lies in the background of many comparative studies concerning whole nations or regions conducted during the past decades (Castells, 2009; Pomeranz, 2000; Jones, 2003; Oesterdiekhoff, 2005; Sanderson, 1995; Osterhammel, 1989).
Despite many differences concerning details there yet exists a common bracket that unifies the classical comparative studies to those conducted during the recent decades. Already the classical comparative studies especially those conducted by the sociologists tried to find the factors that caused the origination of the modern, industrial society. Similarly contemporary comparative studies scrutinize the causes behind modernization and industrialization of certain world regions and nations. Both classical sociology and contemporary comparative studies research the causes to stagnations respectively advancements. Especially the classical sociology (e.g., Comte, Spencer, Durkheim, Weber, Elias) tried to answer to the question why modern, industrial society developed at first in the Western World and not in Asia (Schäfers, Oesterdiekhoff and Dux, in press). Current comparative studies prefer to study why China recently developed better than Russia and India and why Latin America did not achieve the growth rates of Eastern Asia. Altogether, both the classical and the contemporary comparative studies try to earmark the factors that cause divergent socio-economic developmental courses.

The method applied here in this study is to reveal those structures prevalent in ancient Rome that match to these structures known in cross-cultural psychology, for example animism and magic. These phenomena are clear indicators to certain stages known in developmental psychology. Therefore, the historical description matches to the psychological description harbored by developmental psychology. Then, it is developmental psychology that explains the historical phenomenon (Dux and Rüsen, 2014).

\section{The Roman Empire}

The following considerations aim to compare the ancient Roman civilization (during its imperial era) to the modern, industrial civilization. The Roman civilization was the most developed society within the Western hemisphere during the whole premodern era. Therefore, it was that Western society that approached the most to the type of the modern, industrial society. It was more close to the modern, industrial society than ancient Egypt or medieval Europe had been. The question then arises which differences might have existed between the Roman Empire and modern Europe at the time of 1750 . This problem or question leads to the next question why the Roman Empire did not already start the industrialization and modernization process that took place in Europe after 1750. Finally, this problem is connected to the question why did the Roman Empire collapse, followed by much more primitive cultures, instead of advancing as Europe did after 1750. 
It is possible to widen the perspective. To the comparison between the Roman Empire and modern, industrial society can be added the comparison between the Chinese Empire and the Mughal Empire on the one side and the modern, industrial society on the other side. That means it makes sense to classify the Roman Empire, the Moghul Empire and the Chinese Empire to the same group. Each of the three Empires had some prerequisites to develop the industrial civilization but did not do it. Therefore, the comparative study of these three civilizations is necessary to isolate those factors that caused the processes of modernization and industrialization (Oesterdiekhoff, 2005; Jones, 2003; Sanderson, 1995; Osterhammel, 1989; Pomeranz, 2000; Breuer, 2014).

Since the days of the classic authors numerous approaches have been developed to explain the so-called special course of the West and the corresponding stagnation of the Asian civilizations. There does not exist a thorough and systematic theory to the subject by today that is generally accepted. In the following it is not intended to address the problem directly but to constrain the research question to the scrutiny of the cultural distance or resemblance between the Roman Empire and the modern, industrial civilization.

The Roman Empire harbors between 30 and 50 millions of people. It imposes a unifying system of government, administration and jurisprudence right across the Mediterranean. It builds a huge network of streets and postal services right across the empire. Wall constructions called limes and roughly 300.000 soldiers care for the external security of the empire. It has commercial connections to India and China, to England and the Black Sea. Roman vessels coming from Ostia anchor in Xanten and Londinium, in Alexandria and Constanta. Passenger vessels with 700 travelers each crossed the seas bringing tourists to the pyramides of Gizeh or merchandisers to Cyprus. Division of labor and industrial trades are highly specialized. Parts of tools or goods are made in different factories spread in different nations, then transported to factories that assemble the different parts to the object planned. This kind of economic specialization strongly resembles modern, industrial economy. Aqueducts and sewage systems leading to the single households are common in greater cities, installations usual in modern Europe not before the end of the 19th century. Rich people had fortunes that were reached again only during the first half of the 19th century in Europe. In the later phases of the Empire, the state controlled every single citizen, imposed him his job or profession and checked his tax payments, comparable to recent communist dictatorships (Breuer, 1987; Friedländer, 2019; Breuer, 1998, 2014; Horn, 1987; König, 2004; Oesterdiekhoff, 2005).

Focusing the political system, the complexity of administration, the relevance of international trade, the technological advices, the variety of industrial trades, the amount of the division of labor, the traffic systems and the architecture, then it appears to be apparent that the Roman Empire was closely developed to the stage of modern Europe of 1750, much more than ancient Egypt or medieval Europe. However, there must have been some gaps still existing-otherwise Rome would not have collapsed and would have developed the modern, industrial society. The question arises which gaps still existed and in which areas ancient Rome was weaker developed than 1750 Europe. There must have existed some shortcomings or kinds of backwardness that explain the blockade-and help to explain the breakdown.

As the socio-economic traits of the two types of cultures are so close to each other it makes sense to ask whether the ancient and the modern people are similar or divergent to each other. Perhaps the differences between the two types of society are more easily to detect when the study refers to the people and not only to the socio-economic traits.

Dinzelbacher (2008), a well-known historian of mentality, maintains that the Roman citizen of the imperial period be a modern human being and not to differ from a human being of present day. Correspondingly, Dinzelbacher sees the Roman civilization close to the stage and the standards of modern society. More, Dinzelbacher judges that the medieval European is much more primitive and archaic than both present-day humans and ancient Roman humans.

Some other historians came to divergent conclusions. French historians of mentality such as (LeGoff, 1970; Febvre, 1977) emphasize the still archaic character of the Roman civilization, its mental resemblance to other preindustrial cultures, even to those of Black Africa in pre-colonial times. Friedländer (2019, Darwin, 2009; Tylor, 1871; Frazer, 1994) distinguished also Roman civilization from modern, industrial society, describing its still primitive traits.

It is describable that Roman civilization was advanced in comparison to medieval Europe but backward in comparison to modern, industrial Europe. The average Roman citizen was more archaic than the average European of the 19th century and the latter one was behind the average European of the 20th century. This judgment is already verified upon the knowledge coming from the comparative scrutiny of belief in superstitions (oracles, ancestor worship) and support of cruelties (Roman games, punishment law). 
There are two procedures to determine the psychological developmental stage of people. The knowledge provided by history and ethnology has to be compared with that developmental psychology provides. At first the developmental approach will be presented and then, its notions are applied to the study of mind, worldview, religion and morals. It will be shown that the psychological differences between the ancient Romans and the people living in modern, industrial societies are clearly identifiable and must be connected to the different socio-economic traits of the two types of civilizations.

\section{Developmental and Historical Psychology}

Especially in the time span 1880-1940, but also in the wider period 1800-1970, many authors studying history, ethnology, psychology and sociology maintained or described that ancient, archaic, pre-modern or primitive adults might share psychological traits that are typical for children. To this group have been belonging (Comte, 1988, Elias, 1982, Frazer, 1927; Jung, 1991; Schultze, 1900; Wallon, 1928; Werner, 1948; Werner and Kaplan, 1948). Hundreds of authors that founded several human and social disciplines belonged to those that described such resemblances. Murphy, Allier, Lombroso, Romanes, Vierkandt, Jaensch, Chamberlain, Baldwin, Freud, Abraham, Neumann, Lubbock, Schweitzer, Blondel, Stern, Bühler, Preyer and Tylor belonged to this group. The whole group of early child psychologists shared this view and most early psychoanalysts did so too. In possibly most early studies concerning the development of religion, philosophy, literature, law, morals and worldview there are descriptions that rely on those comparisons. Especially ethnologists, missionaries, medical doctors and officials working in the colonies referred to this comparison. The best early monographs on the subject were written by (Schultze, 1900) and especially by Werner in 1926 (Werner, 1948). He clearly evidenced that the archaic human being shares the whole psychological life with the child, down to every central aspect regarding perception, cognition, logic, worldview, morals, etc.

The discussion entered a new stage with the publications of Jean Piaget from 1920 to 1980. Although he did not dedicate whole monographs to the subject he instead launched respective descriptions in most of his articles and books, mostly in the length of some sections or pages. Nonetheless these short descriptions of resemblances between children and archaic humans cover so many psychological phenomena that every careful reader has to grasp that developmental or child psychology must be crucial to any kind of historical psychology (Oesterdiekhoff, 2016a; 2016c; 2016d; Ibarra, 1994). In case someone would collect the respective descriptions of Piaget he could create a monograph matching to that of Werner mentioned. More, Piaget himself repeatedly remarked that child psychology is a method for him to study the psyche of ancient humans and ancient philosophy. Though Piaget did not write a monograph that dealt with the whole psychological life of ancient humans, as Schultze, Lombroso, Murphy, Allier, Romanes, Chamberlain and Werner had done, he wrote some books that reconstructed the history of sciences in terms of psychological stages (Piaget and Garcia, 1989).

Before following the traces of Piagetian research it should be outlined the history of discussion in the past 50 years. The Swiss sociologist (Ziégler, 1968) worked out the role of developmental psychology to the study of sociology, of developing and developed societies, relying on the resemblances between children and archaic humans. The German sociologist (Habermas, 1989) did the same a few years later in a book finding a great audience. Greater breakthroughs came with the books of the ethnologist Christopher (Hallpike, 1979; 2004) who combined ethnology and developmental psychology, something Schultze, Werner, Vierkandt, Jaensch, Murphy, Allier and some others had done beforehand. Gablik (1976) reconstructed the history of arts in terms of psychological stages and (LeGoff, 1970) did the same regarding the history of English literature. Ibarra (2007) interpreted pre-Columbian Maya and Aztec cultures in terms of psychological stages, (Radding, 1985) did the same regarding medieval Europe.

Oesterdiekhoff (2009a; 2011; 2012a; 2013a-b; 2016c; 2018a) developed the so-called structural-genetic theory programme that aims to reconstruct the whole history of mankind, the history of language, population growth, economy, society, culture, sciences, philosophy, religion, worldview, politics, law, morals, arts, literature and music. It is described that the developmental approach is able to deepen the grounds that base the historical trends of each of the domains mentioned. It is maintained that the developmental approach is ought to underlie every single human and social discipline as the most fundamental theory in each of the disciplines and should unify them all under one common roof too.

Thus, despite the replacement of the developmental approach by mainstream philosophies such as cultural relativism (cultures and peoples are not comparable to each other against general standards) and universalism of mind (every nation or folks have the same amount of intelligence and rationality) during the decade 19701980 (Oesterdiekhoff, 2017c), stepwise increasing by today and almost unquestioned by most current social scientists, there were some dozens of scientists during the past 50 years who followed the earlier traditions of describing resemblances between children and archaic 
adults. More, among them were highly estimated authors such as (Habermas, 1989 Ziégler, 1968). Further, the evidence to the theory is now much greater than it was beforehand, especially due to the achievements contributed by the structural-genetic theory programme.

Decisive data came from Piagetian cross-cultural psychology, starting during the thirties and reaching its peak between 1950 and 1990. More than 1.000 empirical surveys right across numerous milieus, ethnicities and cultures were conducted, concerning hundreds of Piagetian tests. These surveys evidenced the theory of the psychogenetic development of humankind, in a way its 19th century supporters could only dream of. Before discussing these cross-cultural findings it is necessary to present Piaget's stage theory.

Most of that what Piaget described regarding the development of the child was described before him or next to him by other authors (Stern, 1924; Luria and Wygotski, 1992; Werner, 1948; Wallon, 1928). A close view in the bibliography of the books of Werner and Stern show this very clearly. Possibly the best comprehensive book on child development that has been ever written by now is that of (Stern, 1924). However, Piaget was best in thorough analysis of the data and their systematic presentation and description. Piaget discriminates four stages of human development. The first stage that of the infant, is called sensory motor stage, lasting by the 18th month. It is followed by the preoperational stage in which the child develops language and reasoning, anticipation and memory capacities. Though the child now knows how to act and to participate at society he or she has some shortcomings due to the low developmental stage. The preoperational child has a wild fantasy and imagination, believes in myths and legends, in sorcerers, witches, magicians and ghosts, in magic and superstitions and in oracles and miracles. His or her's logic and rationality are still underdeveloped. The child cannot carry out syllogistic conclusions and has underdeveloped understandings of causality and chance. He or she cannot conserve physical entities such as volume, mass, time, length, etc. The second stage lasts by the sixth or tenth year respective of the tasks involved. The third stage-that of the concrete operations-comes into being with six years and lasts by the 12 th year of life roughly. Now the child has a better understanding of nature and of causality and chance. His or hers inclination to magic and superstition diminishs tremendously.

The fourth stage of human development, the stage of the formal operations, originates in the child aged 12 roughly and stepwise unfolds and increases by the age of 20 or 25 . It is divided in the sub stages A and B, the latter one originating with 15 years. This stage establishes combinatorial, systematic, reflective, experimental, abstractive and logical abilities. The child this stage understands theories and develops basic faculties in understanding sciences. The whole psychology of the child with its inclination to magic and superstition, myths and legends, egocentrism and irrationality comes to an end. The formal operational adolescent develops the understandings for sciences, democracy, humanism and civil society, all those basic attitudes that are required to lead a life in a modern, industrial society (Piaget and Inhelder, 1969; Piaget, 1932; 1959; 1969; Mogdil and Mogdil, 1976).

Piagetian cross-cultural psychology found that the tests measuring the respective stages could be applied to peoples from different cultures and ethnicities without any crucial problems. All humans develop the first two stages. The third stage (concrete operations) develops stronger in modern than in premodern societies. While every sane child in the modern world develops it, people living in folk societies (Redfield), in backward regions within the developing nations and in hunter and gatherer or nomadic societies do not develop it at all or only partially. Typical results from the tests conducted during the 20th century were that only smaller percentages of people living in such premodern conditions develop the third stage and then only in some areas and not in others (Dasen and Berry, 1974; Dasen, 1977; Cole and Scribner, 1974; Hallpike, 1979; Luria, 1982; Mogdil and Mogdil, 1976; Peluffo, 1967; Werner and Kaplan, 1948; Oesterdiekhoff, 2009a; 2011; 2012b; 2013b; 2016c-d).

It is obvious that in former times, those where people were not influenced by modern cultural contacts, primitive and archaic people did not develop the third stage at all. It may have had some relevance among educated people in the great ancient civilizations. According to Piaget himself, the concrete operational stage was developed by the Ionian philosophers, while he saw the preoperational stage as sufficient to describe the mental life of primitive societies. In fact, the whole ethnographic literature describing mind, worldview, customs and behavior of primitive people totally matches the descriptions of the preoperational stage. The correspondences are overwhelming and clear (Fortune, 1963; Gillies and Evans-Pritchard, 1976; Lévy-Bruhl, 1923; 1971; 1983; 1985; Frazer, 1927; 1994; Tylor, 1871; Oesterdiekhoff, 2009a; 2011; 2013a; 2012a; 2016a; Wallon, 1928; Werner, 1948).

According to Piaget, the formal operational stage came into being in the mind of 17 th century scientists enabling them to erect the physical sciences (Piaget and Garcia, 1989; Oesterdiekhoff, 2017b). From there it spread through the educated classes of the 18th and 19th centuries and reached the whole population not before the 20th century. Thus, the formal operational stage increasingly conquered the psychological life of people 
in modern societies during the past 350 years. Now 30$50 \%$ of people living in the today's most advanced nations develop substage B of formal operations, while $50-70 \%$ of this people develop substage a only (Oesterdiekhoff, 2000; 2014a; 2014b; 2014d; 2016cd; Mogdil and Mogdil, 1976; Flynn, 2007).

With globalization generally and colonization of the South specifically, the modern world contacted the premodern world in an unprecedented way. The modernization and industrialization of the developing continents was accompanied by the psychological growth of the peoples. The preoperational stage dominated the peoples of the Third World around 1900 remarkably and clearly, as all ethnographic literature and early psychological tests evidence. There has been a steady growth of the higher stages during the past generations. Piagetian tests have yet shown that these peoples distribute on the preoperational, concrete operational and formal operational stage by now, depending from divergent social, cultural andeducational backgrounds (Luria, 1982; Luria and Wygotski, 1992; Cole and Scribner, 1974; Dasen, 1977; Everett and Everett, 2009; Hallpike, 1979; Oesterdiekhoff, 2000; 2009a; 2011; 2012a; 2013a; 2017c; Dux, 2017).

It was found that archaic or premodern adults share with children the whole psychological life apart of life experience and knowledge (that what does not depend from stage structures). Everything what developmental psychology knows to describe the psychology of the child matches that what cross-cultural psychology and ethnography had described too regarding premodern adult humans. It is not so that premodern adults share only some traits with children but resemble modern adults in other aspects. Instead the commonalities refer to the smallest details and do not spare any aspect. The commonalities comprise the whole stage structures concerning the development of understanding logic, physics, social affairs, politics, law, religion, etc. They comprise the whole field of mind, consciousness, psyche and personality (Oesterdiekhoff, 2009a; 2011; 2013a-b; 2016c-d).

In fact, all psychological stages developmental psychology describes were once developmental ages of people. All intermediary stages possible between stages of early child and sophisticated formal operational thinker once existed or still exist today anywhere in the world. The greatest part of premodern humankind did not develop beyond the seventh developmental year, some smaller percentages climbed to the 10th developmental year. Mental ages of adolescents aged 12 or 14 were rarely spread in ancient civilizations and became more frequent in Europe after 1700. Adolescent mental ages now define the normal stage summits in the most advanced nations. Altogether, premodern mental ages do not surmount the 10th year usually, while modern mental ages distribute between 12 and 25 . To my opinion these facts are not only the most interesting phenomena in psychology but in the whole area of humanities and social sciences. They have the greatest explanatory power (Oesterdiekhoff, 2018a; 2016c).

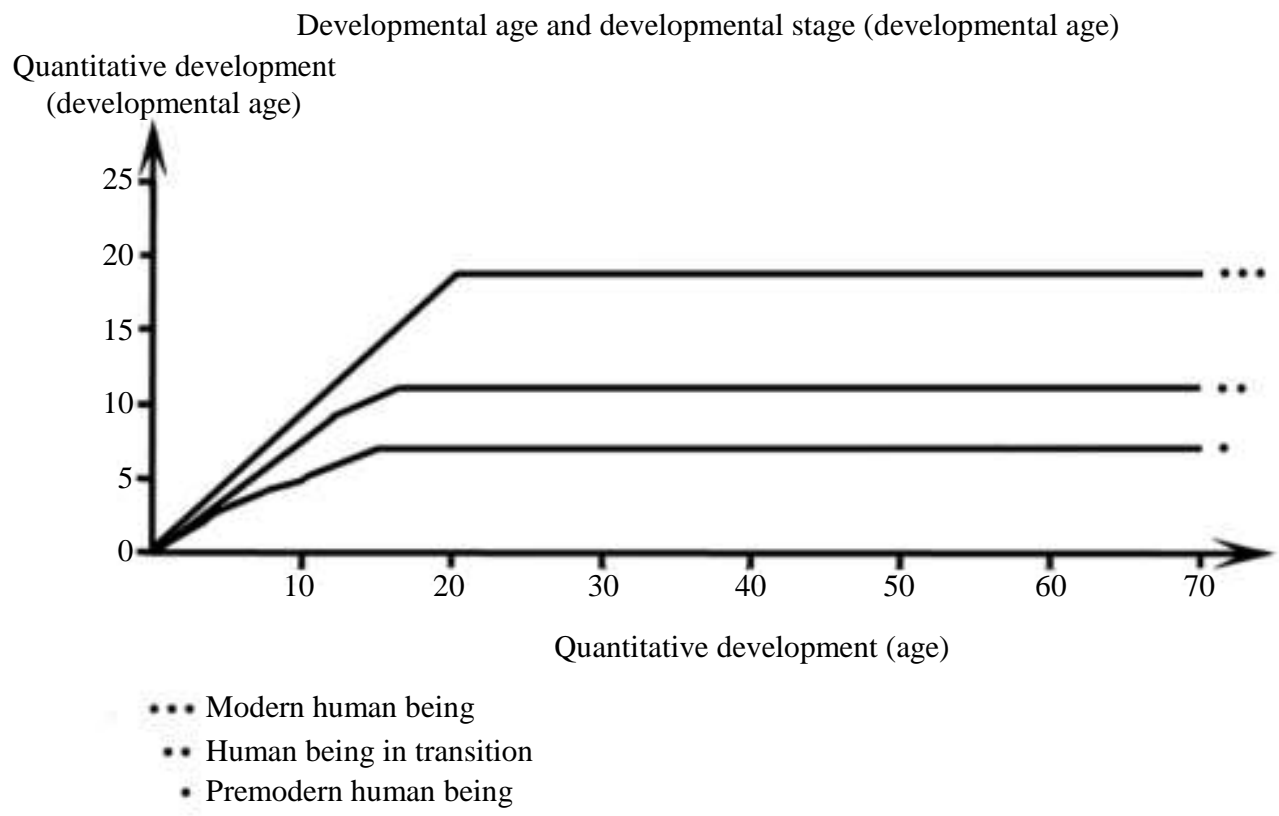

Fig. 1: Different developmental courses 


\section{The Reconstruction of History in Terms of Psychological Stages}

Here is not the place to outline the reconstruction work mentioned at length. Therefore only some short remarks should illuminate that only developmental psychology has found the key to describe the true foundations of the historical development of language, psyche, logic, rationality, population growth, economy, society, politics, law, sciences, philosophy, religion, arts and literature (Table 1). As children very young the early languages only have main sentences and avoid subordinate clauses. Both forms of language share onomatopoetic traits and tend to syllable duplication. Both don't have initially word order, disjunctions, conjunctions, tenses, passive and plural. As children gradually learn the forms of full grammar during their preschool years some languages developed them during the Bronze Age, others haven't developed them by now (Oesterdiekhoff, 2018b; Everett and Everett, 2009). Both children by their 10th year roughly and premodern peoples do not master abstractive forms of logic such as hypothetical-deductive and syllogistic conclusions (Luria, 1982; Cole and Scribner, 1974; Oesterdiekhoff, 2009a; 2011). The same groups share underdeveloped understandings of causality, chance, probability, necessity and possibility (Piaget, 1969; 1959; Oesterdiekhoff, 2009a; 2011; Gillies and Evans-Pritchard, 1976; Lévy-Bruhl, 1923).

Instead of having a mechanical and empirical-causal worldview they share a magical-animistic understanding of nature and reality. Everything to them is alive and conscious, including clouds, waters, woods, rocks and artifacts. Both groups assign to animals humanlike minds and capacities so that ancient humankind adored animals as gods or prosecuted them before courtyard (Evans, 1906; Fortune, 1963; Frazer, 1927; 1994; Lévy-Bruhl, 1971; Oesterdiekhoff, 2009a-b; 2011; 2012a; Piaget, 1959; Tylor, 1871; Schultze, 1900; Werner, 1948). Both groups believe that all objects, animals and humans can transform to other kinds at will within a moment. This belief in metamorphosis is only a small part of the belief in magic. Both groups believe that all entities existing in the world can do everything by magic, can magic weather, sunshine, death, birth, sickness, sanity and whichever. Both groups believe in ghosts, sorcerers, witches and fairies. Both groups share a fairy tale understanding of nature and reality and fully believe in legends and myths. Both groups are capable to fancy myths which they take then despite as reportages of true incidents (Daxelmüller, 1996; Fortune, 1963; Frazer, 1927; 1994; Oesterdiekhoff, 2009a; 2011; 2012a; 2013a; Piaget, 1959; Thorndike, 2003; Werner, 1948; Wuttke, 1860).

Ancient people adored planets, stars, woods, mountains, waters, etc. as gods, likewise animals and humans. The worship of nature originates in the personification of dead matter, that is, in the animism of the child (Cicero, 1995; Comte, 1988; DeGroot, 1912; Durkheim, 1912; Frazer, 1994; Oesterdiekhoff, 2011; 2013a; Schultze, 1900; Tylor 1871).

Ancestor worship likewise roots in the mentality of the child. Ancestor worship was omnipresent in the premodern world, in nature peoples and ancient civilizations alike. It means the belief in the full divine nature of the dead parents, grandparents, uncles and aunts. They were believed to govern the life of their children on earth, to be omniscient and almighty and to be depending on food and drink their children bring them in exchange for a good life only the ancestors can allow and create by magic. Ancestor worship originates in the psyche of the preschool child that adores their parents, believing they master world and cosmos, being almighty and omniscient. The greatest part of the premodern humankind, staying on the preoperational stage and sharing the psyche of the preschool child, did never surmount this belief in the divine status of their parents and grandparents throughout their whole lifespan (Bovet, 1951; DeGroot, 1912; Durkheim, 1912; Frazer, 1927, 1994; Fustel de Coulanges, 1923; Oesterdiekhoff, 2011; 2013a; 2015; Tylor, 1871).

Ancient people had a concrete understanding of the divinities. They brought them food and drink to their temples and adored them and spoke to them there. Correspondingly they expected from them help in their lives, believing the gods would care and control everything. As children believe that gods need something to eat and live the life of normal people.

Altogether, premodern religions originate in the mentality of the child. The weaker forms of religion prevailing in more recent centuries manifest intermediary psychological stages. The diminution of religion in history and the rise of agnosticism and atheism since the 18th century, the overall trend of secularization and disenchantment, originate in psychological stage advancements.

The history of law follows the psychogenetic law understanding of the child. The early child supports harsh and severe punishments, as did ancient law by 1800 all over the world, including nature peoples and ancient civilizations (Oesterdiekhoff, 2000; 2009c; 2011; 2012a; 2013a; 2014c; 2017a; Piaget, 1932; Post, 1880; Schild, 1980; Seagle, 1946). Both groups share the phenomenon of objective responsibility, that is, the imprecise earmarking or even negligence of personal guilt in favor for punishments of persons who were not really accountable for the damage (including collective punishment) (Hallpike, 2004; Oesterdiekhoff, 2009a; 2013a; 2014c; Piaget, 1932; Post, 1880; Radding, 1985; Schild, 1980; Seagle, 1946). Both groups prefer oracles to decide over guilt or innocence. Children by their tenth year roughly believe that nature and reality will punish 
any delinquency earlier or later. They cannot believe that guilty persons won't get their punishment deserved. Therefore they ask matches, halms, cars passing, or other objects or incidents to decide what is true and what should be done. Or they fight with their opponents hoping the winner will be in the right. Thus manifests their strong belief that the cosmos guarantees justice and order by itself. This belief underlies the ancient and medieval ordeal practice. From prehistory to early modern times right across the five continents premodern peoples used poison, hot iron or water, competitions of all kinds, questioning of animals and duel combats to decide judicial cases. In most cultures ordeals were the most used and preferred form of jurisdiction (Gillies andEvansPritchard, 1976; Giebel, 2001; Hallpike, 1979; Lévy-Bruhl, 1923; Oesterdiekhoff, 2009a; 2011; 2013a; 2014c; Piaget, 1932; Post, 1880; Schild, 1980; Tylor, 1871).

Both groups regard legislation as made by god and not by humans. Both groups do not distinguish moral and legal laws from physical laws. They see physical laws in terms of moral laws and vice versa. Therefore, they deny democracy and prefer a divine constitution with authorities that lead at behest of God. As modern adolescents replace this law understanding by the discrimination between changeable legal laws and unchangeable physical laws so did humankind during the early modern times. The introduction of democracy and rule of law originates in the establishment of the formal operational stage during the 18th and 19th century (Piaget, 1932; Kohlberg and Gilligan, 1971; Oesterdiekhoff, 2009a; 2011; 2014c; Radding, 1985).

Morals have gone developmental steps according to the general pattern described too (see table 1). Cannibalism, brutal punishment law, slavery and brutal treatment of women, children and animals are omnipresent in archaic societies. Cannibalism exists also in societies with ample food and does not only threaten strangers but also members of own family and clan. Moral hindrances and bad emotions are not recorded in the ethnographic reportages. The Roman arena games are enthusiastically beloved by the audience as the most entertaining spectacle (Auguet, 1994; Baker, 2002; Friedländer, 2019; Grant, 2000; Oesterdiekhoff, 2009c; 2012a). No political party or movements tried to abolish them. These games do not exist anymore in the modern world because modern citizens reject to see beast or people murdered for entertainment reasons. Already (Darwin, 2009) saw the arena games as best proof of the underdeveloped psyche of the ancients in terms of emotions and morals. The formal operational stage with its higher moral stages (Kohlbergian stages 4, 5 and 6), slowly developing after 1700 in Europe, caused the abolishment of these primitive forms of social behavior and the origination of humanistic ideas and practices (Hallpike, 2004; Kohlberg and Gilligan, 1971;
Oesterdiekhoff, 2000; 2017a; 2012a; 2013a; Piaget, 1932; Pinker, 2012).

Sciences in stricto sensu are possible only against the establishment of the formal operational stage. As adolescents in modern societies develop this stage as they establish the basic understandings to sciences. The 17 th and 18th century scientists did the same, thus developing chemistry, physics, geology, biology, medicine, mathematics and the social and human sciences. The steam engine of Watt and Boulton is the result of this revolution in sciences, especially of developments in chemistry and physics. Thus, industrial society, starting with steam engines and railways, originates in the psychological stage developments of Western people taking place at that time (Oesterdiekhoff, 2011; 2012a; 2013a; 2014a; 2014b; 2014d; 2017b; Piaget and Garcia, 1989).

Ancient philosophy and metaphysics mainly base on animism, magic and purposiveness, that is on the magical-animistic belief system of the child. The mechanical philosophy of the 17th century surmounted ancient metaphysics, in consequence of the rise of the formal operational stage. Platos theory of ideas and the medieval theory of the universals originate in the socalled conceptual realism of the child. The theory of ideas is a theory of mind and nature likewise. It sees ideas as makers of the material objects the cosmos consists of and assigns to these ideas a supernatural status. Likewise it maintains a supernatural and mystical nature of the ideas humans have in their heads. Mystical ideas are the makers of objects and mind likewise. It could be shown that children share this view fully. This confusion of psyche and physics, mind and matter, subjective and objective, idea and object characterizes the mind of the child and that of ancient philosophy. It is surmounted only by the formal operational stage, that is, in early modern philosophy by Descartes and Hume (Weiß et al., 2021).

As children and ancients do not discriminate subjective and objective as they believe words and things are connected by an internal link. This view is held by Plato (Kratylos) and Aristotle, by medieval scholastic philosophers and by nature peoples all over the world. Likewise children and ancients do not discriminate dream (subjective) from reality (objective). Both groups believe that dreams are either perceptions of real incidents happening in the mystical world or visits of their souls at real places. In any case, they ensue consequences in real life of incidents they had dreamt of. There is a deep connection between realistic dream understanding, non-differentiation of word and thing and Plato's theory of ideas. All three phenomena prevail by the early modern times (Oesterdiekhoff, 2016b; 2011; 2009a; 2012a; 2013a; Piaget, 1959; Tylor, 1871; Lévy-Bruhl, 1923). 
Table 1: Human development and world history

Typical age in modern societies.
Likewise "mental age" or

"psychological age"

Psychological stage

From birth to 2 years

$2-8$

Sensorymotor Mammal societies

Some premodern societies
Main features of the psychological stage

Practical intelligence in space and time without language.

Weak reasoning abilities and low sense for reality. Fairy tale worldview and childish understanding of physics. Weak understanding of causality, chance, probability, necessity and possibility. Deficits in logical and abstractive mental competences. Numbers are unknown or weakly developed. Animism and personification of nature prevail. Belief in metamorphosis of beings into each other. Belief in magical power over things and beings. Belief in immanent justice (in oracles and ordeals), objective responsibility (punishment of unintended consequences, animals and things) and eternal rules (non-differentiation between physical and social rules). Nature is a part of society and ruled by gods.

Authoritarian forms of social relations and support of severe punishments prevail. Logical operations appear to a certain rate. Kantian categories of reason come into being. Belief in magic disappears gradually. Animistic schemes and other irrational belief systems such as immanent justice or realistic dream understandings persist somewhat. Authoritarian forms of government and severe punishments persist. Intelligence conquers the world of praxis but not the world of theories.

12-25 Formal operations Modern, industrial societies (after 1700) reflective mind and reason, of the adolescent stage of psyche and personality takes
The emergence of abstractive, hypothetical-deductive, combinatorial, logical and place. It implies a breakthrough of rationality, foresight, responsibility and morality. The preconditions to the scientific, mechanical and empirical-causal worldview emerge. Disappearance of magical beliefs, animistic schemes, immanent justice, objective responsibility and other forms of mysticism. Disenchantment of the worldview. Emergence of sciences and modern, industrial society. Start of the humanitarian revolution, democracy, rule of law and liberty rights. Transformation in gender relations and punishment law, abolishment of slavery and feudalism. The adolescent stage causes therefore both modern personality and modern society.
The development of the fine arts is mainly shaped by the psychological stage structures. Ancient, medieval and Oriental painting does not involve Euclidean and projective spaces and therefore does not care for distances, perspectives, proportions and measurements. It does not take the canvas as medium to present space but to present locals only. Perspectives are not reproduced by threedimensional space, measurements of sizes and distances, oblique views, etc. Shadows, lights and color shades are unknown. The artists paint according to that what they know about an object and do not paint only that what is viewable from a given standpoint. All these features are to find in the drawing and painting of the child during its "intellectual stage" that is by his or hers ninth year roughly. When the child establishes the "visual stage" he or she surmounts the shortcomings mentioned and develops the Euclidean and projective space understandings, including perspective and realistic copying. The European Renaissance artists were the first in the world history of arts to establish the "visual stage". From 1400 onwards there has been a growing competence to draw and to paint nature and reality as it is truly given to the senses, later on not any more distinguishable from photos (Gablik, 1976; Oesterdiekhoff, 2013a; Oesterdiekhoff et al., 2019).

\section{Ancient Roman Civilization Compared to Modern Industrial Society}

\section{Animism}

Animistic views play a central part in ancient culture and civilization. Ancient people generally believe that waters, woods, mountains, winds and stars are alive and conscious. Woods and winds are adored and frightened. They receive sacrifices and are asked for magical assistance given to the good of the praying people. The Romans adore the planets as gods, likewise do they adore all elements of nature such as woods, waters, mountains, or artifacts such as swords or aquaeducts, or trades such as jewellery or forge, or traits such as ambition or braveness, as true goods. They built temples to adore and to sacrifice for these divinities. The ancients took storms as intentional attacks of winds and waters against seafarers in order to punish them for their sins. Therefore, captains, before their voyages, sacrifice to the waters in order to prevent them of being aggressive. Ancient astronomy understood the stellar movements as movements comparable to those of living beings, movements following intentions and morals (Cicero, 1995; 1989; Frazer, 1994; Jung, 1991; Lafiteau, 1724; Tylor, 1871; Schultze, 1900).

The ancient Romans share their animistic view with all other premodern cultures. The premodern people of India and China manifest the same animistic views as the ancient Romans and Mediterranean people (DeGroot, 1912). Animism is a main feature of the worldview of nature peoples and archaic societies (Lévy-Bruhl, 1971; Fortune, 1963; Schultze, 1900; Tylor, 1871; Waitz, 2017; Wundt, 2015; Wuttke, 1860). Empirical surveys conducted in the frame of cross cultural psychology during the 20th century could evidence that animistic views prevail in all nations that live in traditional or premodern social settings and vanish only in peoples living in industrial societies (Havighurst and Neugarten, 
1955; Mogdil and Mogdil, 1976; Kälble, 1997; Peluffo, 1967). While animism vanished from the 17 th century onwards to disappear in the modern crowds during the 19th and early 20th centuries, it still exists in smaller or greater parts of people living in developing nations. Even in the countryside of Turkey it was strong still 30 years ago, as it was surveyed there (Kälble, 1997). Of course, Turkish, Brazilian or Mexican seafarers usually do not sacrifice any more to the waters and winds. However, animism is still strong in Africa, the Andes or some parts of Asia with a lot of archaic elements involved (Oesterdiekhoff, 2011; 2013a; 2009a).

Animism is a normal part of child development in industrial societies. The younger the children are the stronger animistic beliefs persist. To children very young even stones, houses, doors and cups are alive, as it is being reported from some nature peoples. Animism declines very early and restrains then to objects moving (clouds, cars, waters), excluding those that don't move (rocks, stones, houses). With 9 or 10 years finally modern children discriminate dead matter from living beings strongly. Planets and stars are the last entities viewed in terms of animism, even up to the 12th year roughly. Altogether, children during their first decade confuse psyche and physis, subjective and objective, life and matter, biology and physics (Piaget, 1959; 1969; Werner, 1948; Luria and Wygotski, 1992; Mogdil and Mogdil, 1976; Stern, 1924).

Animism is a core manifestation of the child's developmental stage, that is, of the preoperational and partially of the concrete operational stage. The child's psyche and animism are two parts of the same medal. It is the formal operational stage that erases animism completely. It is the adolescent developmental stage that eliminates animism. The formal operational stage replaces animism by the empirical-causal category and the mechanical view. The formal operational stage conquers the crucial discriminations between life and matter, psyche and physis and living beings and material objects (Piaget, 1959; Oesterdiekhoff, 2011; 2013a-b; 2016c-d).

Accordingly the animism of the premodern world solely originates in the animism of the child. As the animism of the child originates in certain developmental stages, as the animism of the premodern world likewise originates in the child's developmental stages and in nothing else. Consequently, the premodern animism is a full empirical evidence to the fact of the preoperational (or concrete operational) stage of the premodern humankind (Oesterdiekhoff, 2016d; 2013a-b; 2011). Premodern animism evidences the total lack of the formal operational stage in the mind of the premodern humankind respectively in the minds of the ancient Romans. Conversely, the replacement of animism by empirical-causal categories and by the mechanical worldview during the 17 th century solely roots in psychological stage advancements having taken place in the minds of the scientists (Oesterdiekhoff, 2017b). Further, the following steps taken by the normal people with this regard is a clear empirical indicator to the psychological advancement having taken place in the normal people living in industrial societies during the time span 1700-1950.

\section{Magic}

Animism and magic belong to each other, ontogenetically and historically. Humans in ancient Roman civilization believe in sorcerers and witches, in magic and oracles. Normal humans are believed to magic winds and weather, sanity and death. Belief in witchcraft and sorcery in ancient Rome is comparable to those beliefs to find everywhere in the premodern world. Beliefs and practices are quite similar around the world. The Romans magic love, peace, wealth, sanity, good harvest, childbirth for their own advantage, or death, misfortune, sickness, etc. for their enemies. May be that these beliefs and practices weakened during the more sophisticated Imperial Times but they never really vanished. Accordingly, the ancient Romans used oracles basing on the observation of the flights of birds or intestines of swines astonishingly similar to practices of the Dayaks in Borneo 100 years ago (Lévy-Bruhl, 1923; Cicero, 1989). Epidemics of prosecution of witches raced through the landscapes from time to time, bringing the prosecuting people to rage and the victims to horror (Luck, 1990; Soldan and Heppe, 1986; Thorndike, 2003; Friedländer, 2019). These epidemics resemble to comparable raids in medieval Europe, or Black Africa and India not long ago. Witches in ancient Rome had the same features as in medieval Europe, Black Australia, pre-Columbian America, Africa or Asia: They fly through air, magic harm and death, eat their victims at nocturnal visits and connect themselves with animals and devils (Gillies and Evans-Pritchard, 1976; Daxelmüller, 1996; Fortune, 1963; Oesterdiekhoff, 2012a; 2013a; 2011; Breuer 1989).

Only developmental psychology-not sociology or ethnology (by their superficial traditional approaches) -is able to explain the origins and the worldwide dissemination of the belief in witchcraft. Developmental psychology from its very beginnings discovered that belief in witchcraft is an inevitable part of the psyche of the child. To the child, everything is made by magic. It believes in its own magical power and in that of parents, adults and gods. Likewise every (!) child initially believes in ghosts, monsters and witches no matter where it is socialized. Belief in witches is simply a manifestation of developmental stages and not of certain ideologies, customs, traditions and cultures. Therefore, this phenomenon is really universal and inevitable 
during certain developmental years. Especially during the preoperational stage the child believes strongly in magic, explaining all the things around by magical assumptions. The concrete operational stage implies a severe weakening of magical beliefs, while the formal operational stage does not know anymore such beliefs. The magic of the preschool child closely resembles that of the greatest part of premodern humankind (Piaget, 1959; Oesterdiekhoff, 2011; 2012a; 2013a; 2016d; Jung, 1991; Stern, 1924; Werner, 1948).

The decline of the belief in magic in Europe started during the 13th century, reaching a decisive stage during the age of Enlightenment and ended roughly 1950. During the 19th century, belief in witches and sorcerers was still widespread only in the countryside or in uneducated people (Wuttke, 1860; Waitz, 2017; Soldan and Heppe, 1986). Altogether, belief in magic and witchcraft was strong in the most advanced nations of Europe by 1750 or 1800 roughly. The decline of magic in the Third World started during the 20th century and has not reached the point of elimination by now.

If one only knew the magical beliefs of the ancient Romans this would be sufficient to evidence their childlike psychological stage. Thus, magical beliefs are a clear empirical indicator to the preoperational developmental stage of the premodern humankind. Conversely, the decline of magic during the past generations reflects the psychological stage advancement of the humankind. The Europeans started with this, the other continents followed more or less successfully. The erasure of the belief in magic and witchcraft within modern, industrial societies evidences the prevalence of the formal operational stage as the modal stage of the people (Oesterdiekhoff, 2011; 2012a; 2013a; 2016d).

\section{Religion}

The ancient Romans adore as gods sun and rivers, human characteristics such as passions and virtues, buildings and animals. They sacrifice humans to gods and adore humans as gods too. Especially they adore their ancestors as gods. Ancestor worship played a big part in Roman religion. As every other premodern religion the ancient Romans adored their dead parents, grandparents, uncles and aunts. They were believed to control the life of their children, to punish them by misfortune when they committed sins or forgot to bring food and drink to their dead parents and to reward them by luck when they led a life according to the customs and to morals. There was a tendency to interpret all mishap by ancestral punishment and all luck by divine reward too. Thus, the ancient Romans believed that their life was in the hands of their dead parents. The magic of the dead controlled the life of their descendants on earth. Therefore the living humans prayed to their dead relatives and felt dependent on them (Cicero, 1995; Friedländer, 2019; Fustel de Coulanges, 1923; Oesterdiekhoff, 2009a; Oesterdiekhoff and Strasser, 2018).

This ancestor worship was also prevalent in China by the 20th century, in India, Africa and other parts of the Third World partially by now, in Black Australia and Indian America throughout times and in Europe by the eve of Christianization. Though, some elements of dead cult were existent in Europe by the age of Enlightenment (DeGroot, 1912; Durkheim, 1912; Fortune, 1963; Frazer, 1994; Lévy-Bruhl, 1971; 1983; Oesterdiekhoff, 2011; 2013a; 2015; Tylor, 1871; Wundt, 2015).

How can sciences explain the universality of ancestor worship in the premodern world, that is, its mere existence, its dissemination and its decline during the modernization process? Which psychological conditions must be given to explain the belief into the power of the dead? Developmental psychology described that children assign to parents (and to adults generally) magical powers and supernatural knowledge and omnipotence. Bovet (1951) coined the terms „deification of parents "and family religion" to describe the religious feelings preschool children have with regard to their parents. Children with seven years roughly start to discover the many shortcomings their parents have and to withdraw the religious status from their parents in order to transfer religious feelings to the gods of their culture where they live in.

This phenomenon is the key to explain ancestor worship. Ancient or premodern adult humans preserve lifelong the religious feelings of children towards their parents. These peoples don't experience the critical phase of children in modern societies in which they surmount the religious feelings towards their parents. They believe in magic, power and divinity of their parents throughout their whole life. Ancestor worship is the continuation of the religious feelings towards parents after their death. It provides the lifelong continuance of the religion of the child. More, ancestor worship is a clear empirical indicator to the preoperational stage of the ancient adult human, or to the childlike developmental stage he is determined and characterized by.Only humans living in modern, industrialized nations have surmounted this family religion because they are the only ones that stay on developmental stages beyond that of the child (Oesterdiekhoff, 2015; 2013a; 2011; 2009a).

\section{Morals and Passions}

Darwin (2009) argued in 1872 that civilization in stricto sensu might be a very recent phenomenon, coming into existence during the age of Enlightenment or even later on. Darwin continued that humanistic thought and higher morals might have developed only 
some decades ago, that is, during the first half of the 19th century. He added that Roman civilization was barbaric in comparison. He referred to the Roman arena games as empirical indicator to his thesis mentioned. He wrote that it would be impossible to restore these games in modern Europe of 1872. At the same time roughly (Friedländer, 2019) came to very similar conclusions. According to him, the crowds of Europe in the middle of the 19th century wouldn't accept and stand the Roman games anymore as moral feelings and emotions had advanced a lot in comparison to those that characterized the ancient Romans.

The arena games took place in all parts of the Roman Empire over many centuries up to the end of the empire. They comprise deadly duels, chases of animals and execution of delinquents, the latter one often accompanied by mutilation. Often historians maintain the games existed in order to symbolize the power of the emperor of Rome, or the power of civilization upon nature and beasts. These alleged explanations are surely wrong. Instead the games existed because the people wanted to see the fights and the cruelties. The people enjoyed what they saw in the arena. Thus, the games existed to satisfy the wishes of the crowds. The games were the main part of the whole entertainment culture of the empire, next to the chad races. There were no political parties or movements that intended to abolish these games because they were accepted and supported by the whole people (Auguet, 1994; Baker, 2002; Grant, 2000).

The arena games reflect not only the emotions and the morals of the Romans but also those of the whole premodern world. The Roman games differ from customs omnipresent in the whole premodern world only by their splendid and gigantic frame. Therefore, the analysis of the morals of the Roman games is transferable to the analysis of the morals of the whole premodern humankind. The first part of the Roman games-the gladiator fights-represent deathly duels that are to find as general customs throughout the whole premodern world, including nature peoples, ancient and medieval civilizations. Only the modern, industrial world abolished duel culture as regular custom and lore (Elias, 1982; Hallpike, 2004; Lafiteau, 1724; Oesterdiekhoff, 2000; 2011; 2013a; 2012a; 2017a; Pinker, 2012). The second part of the Roman games-the execution of delinquents-was likewise a regular custom throughout the whole premodern world. Execution with mutilation before the people was practiced right across the five continents from Stone Ages to the beginning of the modern world. Nature peoples and medieval civilizations in West and East used very similar methods with this regard. The Western world after 1750 was the first civilization in world history to abolish this barbarism (Post, 1880; Schild, 1980; Seagle, 1946; Oesterdiekhoff, 2017a; 2011; 2012a; 2013a; Rüsen and Spariosu, 2012).
The third part, chases of animals-agonal fights between beasts or between humans and beasts-are typical phenomena in every ancient or medieval civilization. Weakened rests of these chases are to find nowadays in Spain (bull fights) or as dog or coq fights in developing nations. Animal protection as collective movement was born during the age of Enlightenment in Europe (Oesterdiekhoff, 2009c; 2012a; 2011; 2013a). Altogether, all three elements the Roman arena games consist of have existed throughout the whole premodern world and throughout all continents and times. The first culture to abolish them was the Western culture during the age of Enlightenment and some decades to follow.

Every three core elements of the arena games died out during the beginnings of the modern industrial society in Europe for the first time in history. Darwin and Friedländer (2019) rightly judged when maintaining that humans living in modern, industrial societies had progressed in their socio-moral sentiments and that this advancement of morals, empathy and sensibility had abolished the arena games.

Humans on lower psychological stages manifest cruder attitudes to violence and more primitive socio-moral sentiments. Cross-cultural psychology of morals could evidence that premodern peoples do not develop the adolescent stages of sociomoral judgment but continue the morals of the child lifelong (Piaget, 1932; Kohlberg and Gilligan, 1971; Havighurst and Neugarten, 1955; Hallpike, 2004; Oesterdiekhoff, 2009a; 2011; 2012a; 2013a; 2017a; Radding, 1985). Already (Elias, 1982) and more recently (Pinker, 2012) and Oesterdiekhoff (2000; 2016e) described lower psychological stages as accountable to the higher rates of violence in the premodern world. Accordingly, the younger the children are the more they exhibit physical violence against others. Premodern humans surmount less strongly these childlike forms of using violence in comparison to modern ones.

Ancient Romans (ancient humans) differ from modern humans in two aspects with this regard. At first they want to see humans crying, bleeding, suffering and dying in the arenas for entertainment reasons. Secondly, they are able respectively they have the nerves to be exposed to these cruelties. Modern humans don't want to see this. To witness or to experience such cruelties is exactly that that they abhor more than anything else in their lives. Secondly, they could not stand watching at such horror. Their nerves are too fine and their sentiments are too sensitive in order to be able to overcome the feelings of sadness and empathy arousing from such exposures. Modern humans have therefore a more elaborated consciousness, mind, empathy, sensibility and morals than premodern humans have had (Oesterdiekhoff, 2017a; 2016a; 2013a; 2012a; 2011; 2000; Dux and Rüsen, 2014; Rüsen et al., 2012). 


\section{Conclusion}

The analysis of the branches presented, of animism, magic, religion, violence and morals, is sufficient to evidence that the differences between ancient and modern humans cover the whole range of world understanding and psyche, that is, are not restricted to certain branches or areas. The ancient human being stood altogether on lower psychological stages than modern humans do. Modern humans evolved from preoperational psychological stages to formal operational stages stepwise from generation to generation throughout the last 300 years or so. The ancient Roman citizen instead shared many traits with people called in former times savages or primitives, that is, with nature peoples or stone age peoples. Of course, he was a little bit higher developed although not enough to surmount the psyche of the child. According to (Friedell, 2012), the ancient Roman attained the stage of the 15 th or 16th century European. Therefore, the judgment of Dinzelbacher is wrong who equalized the intellectual level of the ancient Roman to that of the present-day modern human being.

Of course, it would be possible to enlarge the comparisons right across the whole range of psyche respectively understanding physics, social affairs, morals, politics, philosophy, science, arts, manners, etc. A scrutiny of the political life and conduct of the emperors would verify the conclusion drawn. The same has to be said according to the ancient praxis of slavery. Everybody could buy humans on markets and do with them what he wanted to (Oesterdiekhoff, 2013a). Ancient philosophy diverges widely from modern philosophy, manifesting its sources into the range of the preoperational stage (Oesterdiekhoff, 2013a; 2016b).

The question arises whether or not these huge stage differences between ancient and modern humans are liable to the causes of the origination of modern industrial society in Europe respectively why ancient Rome collapsed instead of attaining industrial growth. Without the knowledge the structural-genetic theory programme respectively the notions presented by articles such as this one provide one could presume that it would be sufficient to implant Watt and Stevenson respectively the steam engine and the railway into the ancient landscape in order to arouse industrial growth. Most other things necessary the Romans had already available to change their society and economy. The notions presented here show instead that the whole ancient culture was far away from the stage that would enable to erect the modern, industrial society. The steam engine is a product of the physical sciences having emerged in Europe during the 17 th century; its roots go back to Galilei, von Guericke, Papin, etc. and to the notions of 18th century engineering, chemistry, physics and mathematics. The formal operational stage is the prerequisite and founder of the new physical sciences (Piaget and Garcia, 1989; Oesterdiekhoff, 2017b; 2011; $2012 \mathrm{a} ; 2013 \mathrm{a})$. Without the emergence of the formal operational stage neither physical sciences nor the industrial society would have risen. There is a causal connection of psychological stage, rise of physical sciences and rise of modern society. Of course, the formal operational stage provides the prerequisites for the rise of modern society throughout all fieldseducation, law, politics, morals, etc. -and its causal role is not constrained to the creation of the physical sciences with this regard. The preconditions to this complex developed in 18th century Europe and not in the ancient world (Oesterdiekhoff, 2014a; 2014b; 2014d; 2011; 2012a; 2013a). This is highly remarkable and astonishing.

It would be most interesting to follow this line of argumentation by asking for the socialization conditions lacking in ancient Rome to foster psychological advancement, starting from frequencies of school attendance, level and content of school curriculum and levels of school types, to specifics of maternal communications with children in their early years and to the quality of media and literature. There must be specifics of culture and socialization that disabled higher psychological stages to arrive. Of course, only small percentages of people ever visited schools and they themselves emphasized repetition of texts instead of soliciting reflexive processes (Friedländer, 2019). Thus, it seems that the door is open to answer the questions concerning the link of socialization and psychological stage development when only considering those aspects just mentioned.

It also would be fascinating to determine more exactly the general socialization contexts shaping ancient civilizations such as Rome, India and China on the one hand and their psychological stage positions on the other hand. The results had to be compared to the socialization contexts in early modern Europe. A first hint at that might be the findings of (Jacob, 1997), according to them school curricula of London and Birmingham in early 18th century encompassed Newtonian mechanics, including higher mathematics and physics. There is also to add the wide existence of newspapers, printed books in many middle class homes and scientific circles attracting the intellectual elite of Britain and having an impact on their mind and skills.

\section{Author Contributions}

Georg W. Oesterdiekhoff: Elaborated the first part of the article, developed the idea and read the proof.

Stefan Breuer: Wrote the last part of the article and checked the whole. 


\section{Ethics}

The article does not violate any ethical principles concerning minorities or other issues.

\section{References}

Aristotle, 1995. Gesammelte Werke. Wissenschaftliche Buchgesellschaft, Darmstadt.

Auguet, R., 1994. Cruelty and civilization. The Roman games. Routledge, New York.

Baker, A., 2002. The gladiator. The secret history of Rome's warrior slaves. Ebury Press, London.

Bastian, A., 1884. Allgemeine Grundzüge der Ethnologie. Reimer Verlag, Berlin.

Bovet, P., 1951. Le sentiment religieux et la psychologie de l'enfant. Delachaux et Niestle, Neuchatel/Paris.

Breuer, S., 1987. Imperien der alten Welt. Kohlhammer, Stuttgart.

Breuer, S., 1989. Magisches und religiöses Charisma. Kölner Zeitschrift für Soziologie, 41, 1: 215-235.

Breuer, S., 1998. Der Staat. Rowohlt, Reinbek.

Breuer, S., 2014. Der charismatische Staat. Ursprünge und Frühformen staatlicher Herrschaft. Darmstadt: Wissenschaftliche Buchgesellschaft.

Castells, M., 2009. The rise of the network society. John Wiley, New York.

Cicero, M. T., 1989. Gesammelte Werke. AufbauVerlag, Leipzig.

Cicero, M. T., 1995. De natura deorum. Reclam Verlag, Leipzig.

Cole, M.,\& Scribner, S., 1974. Culture and thought. John Wiley \& Sons, New York.

Comte, A., 1988. Introduction to positive philosophy. Hackett Publishing Company, Indianapolis.

Darwin, C., 2009. Gesammelte Werke. Zweitausendeins, Berlin.

Dasen, P. \& Berry, J. W. (Eds.), 1974. Culture and cognition. Readings in cross-cultural psychology. Methuen \& Co, London.

Dasen, P., 1977. Piagetian cross-cultural psychology. Gardner Press, New York.

Daxelmüller, C. (1996). Aberglaube, Hexenzauber, Höllenängste. Eine Geschichte der Magie. München.

DeGroot, J. J., 1912. The religion of the Chinese. Macmillan, New York.

Dinzelbacher, P., 2008. Das fremde Mittelalter. Magnus Verlag, Essen.

Durkheim, É. (1912). Les formes élémentaires de la vie religieuse, Paris. The Elementary Forms of Religious Life.

Dux, G. \& J. Rüsen (Eds.), 2014. Entwicklung des Denkens. Springer VS, Wiesbaden.

Dux, G., 2011. Historico-genetic theory of culture: On the processual logic of cultural change. Transcript Verlag, Bielefeld.
Dux, G., 2017. Die Zeit in der Geschichte. Wiesbaden: Springer VS.

Elias, N., 1982. Power and civility. Pantheon, New York.

Evans, E. P. (1906). The criminal prosecution and capital punishment of animals. w. Heinemann.

Everett, D., \& Everett, D. L. (2009). Don't sleep, there are snakes: Life and language in the Amazonian jungle. Profile books.

Febvre, L., 1977. Sensibilität und Geschichte. In M. Bloch, F. Braudel, L. Febvre et al. (eds.), Schrift und Materie der Geschichte. Suhrkamp, Frankfurt am Main.

Flynn, J. R. (2007). What is intelligence?: Beyond the Flynn effect. Cambridge University Press.

Fortune, R. F. (1963). Sorcerers of Dobu (1932). New York: Dutton.

Frazer, J. G. (1927). Man, God and immortality: thoughts on human progress. https://ixtheo.de/Record/1191919862

Frazer, J. G., 1994. Collected works, ed. by Robert Ackerman. Curzon, London.

Friedell, E., 2012. Kulturgeschichte der Neuzeit. C. H. Beck, München.

Friedländer, L., 2019. Roman life and manners under the early empire. Routledge, London.

Fustel de Coulanges, N. D., 1923. La cité antique. Étude sur le culte, le droît et les institutiones de la Grèce et de Rome. Librairie Hachette, Paris.

Gablik, S., 1976. Progress in Art. Thames \& Hudson, London.

Giebel, M., 2001. Das Orakel von Delphi. Reclam, Leipzig.

Gillies, E., \& Evans-Pritchard, E. E. (1976). Witchcraft, Oracles and Magic among the Azande. London: Oxford University Press.

Grant, M., 2000. Gladiators. The bloody truth. Penguin books, London

Habermas, J., 1989. On Historical Materialism. Indianapolis.

Hallpike, C. R. (1979). The foundations of primitive thought. Oxford: Clarendon Press; New York: Oxford University Press.

Hallpike, C. R. (2004). The evolution of moral understanding. Prometheus Books.https://psycnet.apa.org/record/2004-21672-000

Havighurst, R. J., \& Neugarten, B. L. (1955). American Indian and white children: A sociopsychological investigation. University of Chicago Press.

Horn, H.-G., 1987. Die Römer in Nordrhein-Westfalen. Theiss Verlag, Stuttgart.

Ibarra, L. (1994). Las dificultades de Jean Piaget para vincular el desarrollo ontogenético y filogenético del conocimiento. Iztapalapa. Revista de Ciencias Sociales y Humanidades, 15(35), 77-89. file://C:/Users/IT\%20Department/Downloads/12363835-1-SM.pdf 
Ibarra, L., 2007. Creencias, mitos y rituales en el mundo prehispánico. Una explicación desde la teoría histórico-genética. Universidad de Guadalajara, Guadalajara.

Jacob, M. C. (1997). Scientific culture and the making of the industrial

West.https://philpapers.org/rec/JACSCA-2

Jones, E. (2003). The European miracle: environments, economies and geopolitics in the history of Europe and Asia. Cambridge University Press.

Jung, C. G., 1991. Wandlungen und Symbole der Libido. DTV, München

Kälble, H., 1997. Die Entwicklung der Kausalität im Kulturvergleich. Westdeutscher Verlag, Wiesbaden.

Kohlberg, L., \& Gilligan, C. (1971). The adolescent as a philosopher: The discovery of the self in a postconventional world. Daedalus, 1051-1086. https://www.jstor.org/stable/20024046?seq=1

König, I., 2004. Vita Romana. Vom täglichen Leben im alten Rom. Wissenschaftliche Buchgesellschaft, Darmstadt.

Lafiteau, J.-F., 1724. Les moeurs des sauvages ameriquaines comparées aux premiers temps. Paris.

LeGoff, J. (1970). Kultur des europäischen Mittelalters. Droemer Knaur.

LePan, Donald, 1989. The cognitive revolution in Western culture. The Macmillan Press, London, New York.

Lévy-Bruhl, L., 1923. Primitive mentality. The Macmillan Press, London, New York.

Lévy-Bruhl, L., 1971. The 'soul' of the primitive. Henri Regnery, Chicago.

Lévy-Bruhl, L., 1983. Primitive mythology. The University of Queensland Press, St. Lucia, New York, London.

Lévy-Bruhl, L., 1985. How natives think. Princeton University Press, Princeton.

Lubbock, J., 1913. Prehistoric times as illustrated by ancient remains and the manners and customs of modern savages. University of California Libraries, Los Angeles.

Luck, G. (1990). Magic and other secret doctrines in antiquity: with 112 newly translated and individually commented source texts. Coroner.https://ixtheo.de/Record/1651230838

Luria, A. R. (1982). Cognitive Development: Its Cultural and Social Foundations Harvard University Press. Cambridge, MA.

Luria, A. R., \& Vygotsky, L. S. (1992). Ape, Primitive Man and Child Essays in the History of Behavior. CRC Press.

Mogdil, C. and S. Mogdil, 1976. Piagetian research. 8 vols. NFER Publishing Comp., London.
Oesterdiekhoff, G. (2009a). Mental growth of humankind in history. BoD-Books on Demand.

Oesterdiekhoff, G. W. (2009b). Trials against animals: A contribution to the developmental theory of mind and rationality. Mankind Quarterly, 49(3/4), 346.https://search.proquest.com/openview/eb08ba0e 38e0a00d9ab66543b240db15/1?pq-

origsite $=$ gscholar $\& \mathrm{cbl}=30967$

Oesterdiekhoff, G. W. (2009c). The arena games in the roman empire: A contribution to the explanation of the history of morals and humanity. Narodna umjetnost-Hrvatski Časopis za Etnologiju i Folkloristiku, 46(1), 177-202. https://www.ceeol.com/search/articledetail id $=231653$

Oesterdiekhoff, G. (2011). The steps of man towards civilization: The key to disclose the riddle of history. BoD-Books on Demand.

Oesterdiekhoff, G. W. (2000). Zivilisation und Strukturgenese: Norbert Elias und Jean Piaget im Vergleich. Suhrkamp.

Oesterdiekhoff, G. W. (2005). Entwicklung der Weltgesellschaft: von der Steinzeit zur Moderne. Lit.

Oesterdiekhoff, G. W. (2012a). Die geistige Entwicklung der Menschheit. Velbrück Wissenschaft.

Oesterdiekhoff, G. W. (2012b). Was pre-modern man a child? The quintessence of the psychometric and developmental approaches. Intelligence, 40(5), 470-478.

https://www.sciencedirect.com/science/article/abs/pi i/S0160289612000712

Oesterdiekhoff, G. W. (2013a). Die Entwicklung der Menschheit von der Kindheitsphase zur Erwachsenenreife. Springer Verlag, Wiesbaden.

Oesterdiekhoff, G. W. (2013b). The role of Piagetian crosscultural psychology to humanities and social sciences. American Journal of Psychology 126, 4: 477-492.

Oesterdiekhoff, G. W. (2014a). The Rise of Modern, Industrial Society The cognitive-developmental approach as a new key to solve the most fascinating riddle in world history. Mankind Quarterly, 54(3/4), 262.

Oesterdiekhoff, G. W. (2014b). Psychological stage development and societal evolution. A completely new foundation to the interrelationship between psychology and sociology. Cultura, 11(1), 165-192. https://www.ingentaconnect.com/content/plg/cultura /2014/00000011/00000001/art00010

Oesterdiekhoff, G. W. (2014c). Evolution of law and justice from ancient to modern times. Journal on European History of Law, 5(1), 54-64. https://www.ceeol.com/search/article-detail?id=159780 
Oesterdiekhoff, G. W. (2014d). The role of developmental psychology to understanding history, culture and social change. Journal of Social Sciences, 10(4), 185-195. http://citeseerx.ist.psu.edu/viewdoc/download?doi=1 0.1.1.1019.5468\&rep=rep1\&type $=$ pdf

Oesterdiekhoff, G. W. (2015). Why premodern humans believed in the divine status of their parents and ancestors? Psychology illuminates the foundations of ancestor worship. Anthropos, (H. 2), 582-589. https://www.jstor.org/stable/43861984?seq=1

Oesterdiekhoff, G. W. (2016a). Is a forgotten subject central to the future development of sciences? Jean Piaget on the interrelationship between ontogeny and history. Personality and Individual Differences, 98, 118-126. https://www.sciencedirect.com/science/article/abs/pi i/S0191886916302513

Oesterdiekhoff, G. W. (2016b). Psychological Stage Development and the History of Philosophy. European Journal of Philosophical Research, (2), 91-105. http://www.ejournal17.com/journals_n/1470833669. pdf

Oesterdiekhoff, G. W. (2016c). Developmental Psychology as Answer to the Question: Can the Human Disciplines Achieve Scientific Foundations Comparable to Biology in Consequence of Darwin, or to Physics in Consequence of Newton and Einstein?. European Journal of Psychological Studies,

68-107. http://ejournal12.com/journals_n/1471877163.pdf

Oesterdiekhoff, G. W. (2016d). Child and ancient man: How to define their commonalities and differences. American Journal of Psychology, 129(3), 295-312.

Oesterdiekhoff, G. W. (2016e). Psychological Development, Violence and the Pacification Trend in World History. European Journal of Psychological Studies, (1), 29-45. http://ejournal12.com/journals_n/1456410045.pdf

Oesterdiekhoff, G. W. (2017a). Evolution of morals in world history. Human Evolution, 32(1), 1-23.

Oesterdiekhoff, G. W. (2017b). The Rise of the Physical Sciences in "Stricto Sensu" The Developmental Approach and the History of Sciences. Physics International, 8(1), 8-23.

Oesterdiekhoff, G. W. (2017c). What went wrong in cross-cultural psychology over the past 40 years? The developmental approach in opposition to two main ideologies of our time, cultural relativism and universalism of mind. Human Evolution, 32(1), 95-138.

Oesterdiekhoff, G. W. (2018a). The first scientific revolution. Human Evolution, 33(1-2), 53-86. file://C:/Users/IT\%20Department/Downloads/10_D isziplinen_2018.pdf
Oesterdiekhoff, G. W. (2018b). Evolution of mind and language. Learning from the Pirahã case, Anthropos, 113, 1: 195-216. https://www.nomoselibrary.de/10.5771/0257-9774-2018-1-

195/evolution-of-mind-and-language-volume-1132018-issue-1

Oesterdiekhoff, G. W. \& H. Strasser (2018).¿Cree usted aún... o ya lo sabe?, Revista Mexicana de Sociologia, Vol. 80, No. 1, 221-231.

Oesterdiekhoff, G. W., Dux, G., \& Hummell, H. J. (2019). The development of painting in history. Psychological stages and sequential epochs. International Journal of Anthropology, 34(3-4), 157-180. https://pontecorbolipress.com/journals/index.php/ija/ article/view/IJA2019341049

Osterhammel, J. (1989). China und die Weltgesellschaft: vom 18. Jahrhundert bis in unsere Zeit.

Peluffo, N. (1967). Culture and cognitive problems. International Journal of Psychology, 2(3), 187-198. https://www.tandfonline.com/doi/abs/10.1080/0020 7596708247215

Piaget, J. (1932). The moral judgment of the child. The Free Press, New York.

Piaget, J. (1959). The child's conception of the world. Littlefield, Adams \& Co., New York.

Piaget, J. (1969). The child's conception of physical causality. Littlefied, Adams \& Co., Totowa.

Piaget, J. (1974). Need and significance of cross-cultural studies in genetic psychology. In Piaget and His School (pp. 259-268). Springer, Berlin, Heidelberg.https://link.springer.com/chapter/10.100 7/978-3-642-46323-5_19

Piaget, J., \& Garcia, R. (1989). Psychogenesis and the history of sciences. Columbia University Press, New York.

Piaget, J., \& Inhelder, B. (1969). The psychology of the child. Basic Books, New York.

Pinker, S. (2012). The better angels of our nature: Why violence has declined. penguin Group USA.

Pomeranz, K. (2000). The great divergence. China, Europe and the making of modern world economy. Princeton University Press, Princeton.

Post, A. H. (1880). Bausteine für eine allgemeine Rechtswissenschaft auf vergleichend-ethnologischer Basis (Vol. 1). Schulze (A. Schwartz).

Radding, C. M. (1985). A World Made by Men: Cognition and Society. University of North Carolina Press, Chapel Hill, NC.https://www.semanticscholar.org/paper/AWorld-Made-by-Men\%3A-Cognition-andSociety\%2CRadding/639c19cd37af8698f27290791fbbda3c0de3 $77 \mathrm{c} 0 ? \mathrm{p} 2 \mathrm{df}$ 
Rüsen, J., Kozlarek, O., \& Wolff, E. (Eds.), 2012. Shaping a humane world. Civilizations-axial timesmodernities-humanisms. Transcript Verlag, Bielefeld.

Rüsen, J. \&M. I. Spariosu (Eds.), 2012. Exploring humanity - intercultural perspectives on humanism. Göttingen: Vandenhoeck \& Ruprecht.

Sanderson, S., 1995. Social transformations. A general theory of historical development. Wiley \& Blackwell, New York.

Schäfers, B., Oesterdiekhoff, G. \& G. Dux (in press). Civilization theory and structural-genetic theory programme. Two fundamental theories in comparison.

Schild, W., 1980. Alte Gerichtsbarkeit. C. H. Beck, München.

Schultze, F. (1900). Psychologie der naturvölker: Entwicklungspsychologische charakteristik des naturmenschen in intellektueller, aesthetischer, ethischer und religiöser beziehung. Veit \& comp.

Seagle, W., 1946. The history of law. Tudor Press, London.

Soldan, W. G. \& H. Heppe, 1986. Geschichte der Hexenprozesse. Magnus Verlag, Kettwig.

Spencer, H., 2017. The principles of sociology. HardPress, Miami.

Stern, W., 1924. Psychology of early childhood up to the sixth year of age. Holt, New York.
Thorndike, L., 2003. The place of magic in the intellectual history of Europe. London.

Tylor, E., 1871. Primitive culture. Two vols. Murray, London.

Waitz, T., 2017. Introduction to anthropology. HardPress, Miami.

Wallon, H. (1928). La mentalité primitive et celle de l'enfant (d'après un livre récent). Revue Philosophique de la France et de l'Etranger, 106, 82-105. https://www.jstor.org/stable/41082549?seq=1

Weiß, J., Papcke S., \& Oesterdiekhoff, G. W. (2021). Philosophy before philosophy. The Dogon cosmology reconsidered. International Journal of Anthropogy, 36, 1-2.

Weber, M. (2019). Economy and society. Harvard University Press.

Werner, H. (1948). Comparative psychology of mental development.https://psycnet.apa.org/record/194903012-000

Werner, H.,\& B. Kaplan, 1948. The developmental approach to cognition: Its relevance to the psychological interpretation of anthropological and ethnolinguistic data. American Anthropologist, 58: 866-880.

Wundt, W., 2015. Elements of folk psychology. Forgotten Books, London.

Wuttke, A., 1860. Der deutsche Volksaberglaube der Gegenwart. Agentur des rauhen Hauses, Hamburg.

Ziégler, J., 1968. Sociologie et contestation. Gallimard, Paris. 